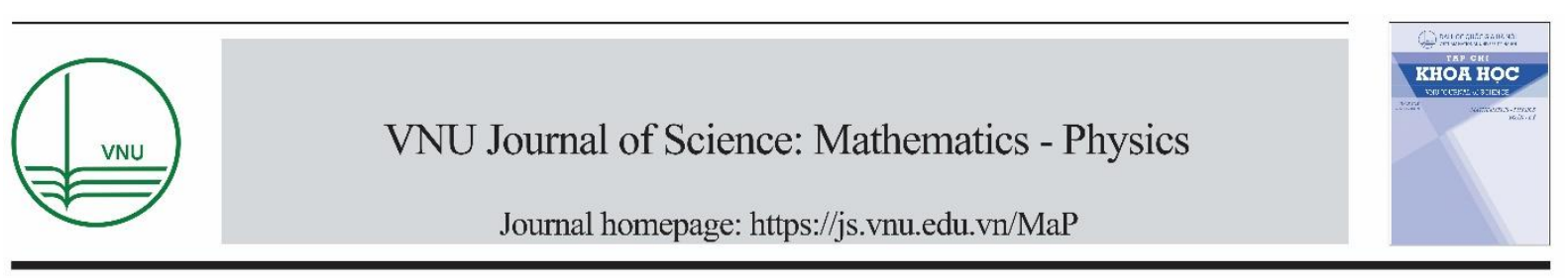

Original Article

\title{
Changing the Magnetic Properties of Cobalt Ferrite Nanoparticles with Different Fabrication Conditions
}

\author{
Nguyen Ngoc Huyen ${ }^{1}$, Nguyen Thi Minh Hong ${ }^{1}$, \\ Pham Duc Thang ${ }^{1}$, Tran Dang Thanh ${ }^{2}$, Ho Thi Anh ${ }^{1, *}$ \\ ${ }^{1}$ VNU University of Engineering and Technology, 144 Xuan Thuy, Cau Giay, Hanoi, Vietnam \\ ${ }^{2}$ Institute of Materials Science, VAST, 18 Hoang Quoc Viet, Cau Giay, Hanoi, Vietnam
}

Received 22 April 2020

Revised 28 August 2020; Accepted 20 September 2020

\begin{abstract}
In this study, crystalline nanoparticles $\mathrm{CoFe}_{2} \mathrm{O}_{4}$ with a spinel structure were prepared by hydrothermal methods. The magnetic properties of non-calcined cobalt ferrite formed from nanocrystalline powders. The dependence of the particle size and crystalline structure of obtained nanoparticles in the synthesis conditions was examined and characterized using field emission scanning electron microscope (FESEM), and X-ray diffraction analysis (XRD). The XRD analysis revealed a high degree of crystallinity and confirmed the spinel structure of crystalline nanoparticles $\mathrm{CoFe}_{2} \mathrm{O}_{4}$. The FESEM image shows the presence of spherical ferrite particles with an average diameter of about 13-18 nm. The results also show that the formation of cobalt ferrite spinel structures was affected by fabrication conditions. Magnetic hysteresis loop data confirm that the magnetic properties of nanoparticles depend on the synthesis conditions. The material prepared by the hydrothermal route and calcination at $150^{\circ} \mathrm{C}$ with molar ration $\mathrm{Co}^{2+}: \mathrm{Fe}^{3+}=1: 2.2$ for 2 hours has higher magnetic saturation than that of the surveyed samples.
\end{abstract}

Keywords: Cobalt ferrite, hydrothermal, magnetic properties.

\section{Introduction}

In recent years, nanocrystalline materials are becoming a subject of intense research because of their unique properties. Magnetic nanoparticles have been of interest for their typical physical and chemical

\footnotetext{
* Corresponding author.

Email address: anhht2508@gmail.com
}

https//doi.org/ 10.25073/2588-1124/vnumap.4514 
properties as well as their potential applications in various fields such as high-density magnetic recording, magnetic fluids, data storage, spintronics, solar cells, sensors, and catalysis.

Among many ferrites, cobalt ferrite magnetic nanoparticles are attracting much attention because of their high coercivity, magnetocrystalline anisotropy, moderate saturation magnetization, chemical stability, wear resistance, electrical insulation, and structure [1]. Structurally, in the inverse spinel of the ferrite, tetrahedral sites are generally occupied by $\mathrm{Fe}^{3+}$ ions, whereas octahedral sites (B-sites) are inhabited by $\mathrm{Co}^{2+}$ and $\mathrm{Fe}^{3+}$ ions [2]. To alter the structure and magnetic properties of ferrite nanoparticles, it is necessary to modify their composition and microstructures via different preparation routes [2]. $\mathrm{CoFe}_{2} \mathrm{O}_{4}$ nanoparticles were previously prepared by a wide array of synthesis routines, such as chemical co-precipitation [3, 4], sol-gel [5, 6], solid-state method [7], solvothermal [8], solution combustion [9-12] and hydrothermal method [13, 14]. For each synthesis method, it was found that the fabrication condition played a key role in determining the structure and magnetic properties of the obtained product. Among these techniques, chemical co-precipitation has been reported to be the most economical one. In addition, the hydrothermal method has been confirmed to be a high rate of production and simplicity.

This paper reports on the effect of fabrication condition on the magnetic properties of cobalt ferrite samples, prepared by hydrothermal processes for the purpose of creating highly magnetic $\mathrm{CoFe}_{2} \mathrm{O}_{4}$ nanoparticles to be used as a raw material to synthesize multi-phase ferroelectric/ferromagnetic material from applications in energy storage devices.

\section{Material and Methods}

Cobalt ferrite nanoparticles $\left(\mathrm{CoFe}_{2} \mathrm{O}_{4}\right)$ were synthesized by using the hydrothermal method. Cobalt nitrate hexahydrate $\left(\mathrm{Co}\left(\mathrm{NO}_{3}\right)_{2} \cdot 6 \mathrm{H}_{2} \mathrm{O}\right)$, ferric nitrate nonahydrate $\left(\mathrm{Fe}\left(\mathrm{NO}_{3}\right)_{3} .9 \mathrm{H}_{2} \mathrm{O}\right)$ and potassium hydroxide $(\mathrm{KOH})$ with a purity of $98 \%$ were used as the precipitating agents and deionized water as solvent. All chemicals were purchased from Guangdong Guanghua Sci-Tech Co., Ltd. The chemical reaction is described by:

$$
\begin{aligned}
& \qquad \mathrm{Co}^{2+}+2 \mathrm{Fe}^{3+}+8 \mathrm{OH}^{-} \longrightarrow \mathrm{CoFe}_{2} \mathrm{O}_{4}+4 \mathrm{H}_{2} \mathrm{O} \\
& \text { * Effect of Mole Ratio of } \mathrm{Co}^{2+}: \mathrm{Fe}^{3+}
\end{aligned}
$$

Initially, we fixed the number of moles of $\mathrm{Co}\left(\mathrm{NO}_{3}\right)_{2} \cdot 6 \mathrm{H}_{2} \mathrm{O}=0.02 \mathrm{~mol}$ and then changed the number of moles of $\mathrm{Fe}\left(\mathrm{NO}_{3}\right)_{3} .9 \mathrm{H}_{2} \mathrm{O}$ from $0.032 \mathrm{~mol}, 0.036 \mathrm{~mol}, 0.04 \mathrm{~mol}, 0.044 \mathrm{~mol}$ and to $0.048 \mathrm{~mol}$ corresponding to the molar ratio of $\mathrm{Co}^{2+}: \mathrm{Fe}^{3+}=1: 1.6 ; 1: 1.8 ; 1: 2.0 ; 1: 2.2$ and 1:2.4.

Then, $\mathrm{Co}\left(\mathrm{NO}_{3}\right)_{2} \cdot 6 \mathrm{H}_{2} \mathrm{O}$ mixed with $\mathrm{Fe}\left(\mathrm{NO}_{3}\right)_{3} \cdot 9 \mathrm{H}_{2} \mathrm{O}$ was dissolved in $80 \mathrm{ml}$ of distilled $\mathrm{H}_{2} \mathrm{O}$. The solution was mixed and stirred at room temperature $\left(25^{\circ} \mathrm{C}\right)$ using a stirring rate of $120 \mathrm{rpm}$ for 15 minutes. $\mathrm{KOH}$ was dissolved in distilled $\mathrm{H}_{2} \mathrm{O}$ and then added stepwise to the reaction mixture until $\mathrm{pH}$ $=12$ was reached. When precipitate was observed at the bottom of the reaction mixture, we transferred all the mixture and precipitate obtained into an autoclave and treated them at the temperature of $150^{\circ} \mathrm{C}$ for 2 hours. The precipitate separated from the solution was washed several times with distilled $\mathrm{H}_{2} \mathrm{O}$ and then was dried at $80^{\circ} \mathrm{C}$ for 12 hours to get the final product, $\mathrm{CoFe}_{2} \mathrm{O}_{4}$

\section{* Effect of Reaction Temperature}

The procedure for making CFO samples is done as stated in the effect of the molar ratio of $\mathrm{Co}^{2+}: \mathrm{Fe}^{3+}$ above. The samples were synthesized for 2 hours at different reaction temperatures $\left(110^{\circ} \mathrm{C}, 130^{\circ} \mathrm{C}\right.$ and 
$150^{\circ} \mathrm{C}$ ) with the molar ratio of $\mathrm{Co}^{2+}: \mathrm{Fe}^{3+}$, which is the ratio for the highest magnetic $\mathrm{CFO}$ result obtained from the survey according to the effect of molar ratio $\mathrm{Co}^{2+}: \mathrm{Fe}^{3+}$.

\section{* Effect of Reaction Time}

The procedure for making CFO samples is done as stated in the effect of the molar ratio of $\mathrm{Co}^{2+}: \mathrm{Fe}^{3+}$ above. The samples were synthesized during different reaction times (from 1 hour to 8 hours) with the molar ratio of $\mathrm{Co}^{2+}: \mathrm{Fe}^{3+}$ and reaction temperature, which is the ratio and temperature for the highest magnetic CFO result obtained from the survey according to the effect of molar ratio $\mathrm{Co}^{2+}: \mathrm{Fe}^{3+}$ and effect of reaction temperature.

The crystal structures of the samples were characterized by XRD using diffractometer XRD EQUINOX 5000 with $\mathrm{Cu}-\mathrm{K} \alpha$ radiation $(\lambda=1.5406 \AA$ ) and the morphology (size and shape) of the particle materials was obtained by field emission scanning electron microscopy FESEM (Hitachi S-4800) at the Institute of Materials Science, Vietnam Academy of Science and Technology. Hysteresis loops were measured at room temperature to the highest field of $8000 \mathrm{G}$ using a vibrating sample magnetometer (VSM) at VNU Key Laboratory for Micro and Nanotechnology - VMINA.

\section{Results and Discussion}

\subsection{Effect of Mole Ratio of $\mathrm{Co}^{2+}: \mathrm{Fe}^{3+}$}

Magnetic cobalt ferrite $\left(\mathrm{CoFe}_{2} \mathrm{O}_{4}\right)$ nanocrystals were synthesized via the hydrothermal method with reaction conditions: Hydrothermal Time $2 \mathrm{~h}$, Hydrothermal Temperature $150^{\circ} \mathrm{C}$ and the number of moles of $\mathrm{Co}^{2+}$ is kept constant $(0.02 \mathrm{~mol})$, and the number of moles of $\mathrm{Fe}^{3+}$ varies in such a way that the corresponding molar ratio of $\mathrm{Co}^{2+}: \mathrm{Fe}^{3+}=1: 1.6 ; 1: 1.8 ; 1: 2.0 ; 1: 2.2$ and 1:2.4.

\section{Crystal Structure}

XRD patterns of some $\mathrm{CoFe}_{2} \mathrm{O}_{4}$ at different molar ratios are shown in Figure 1.

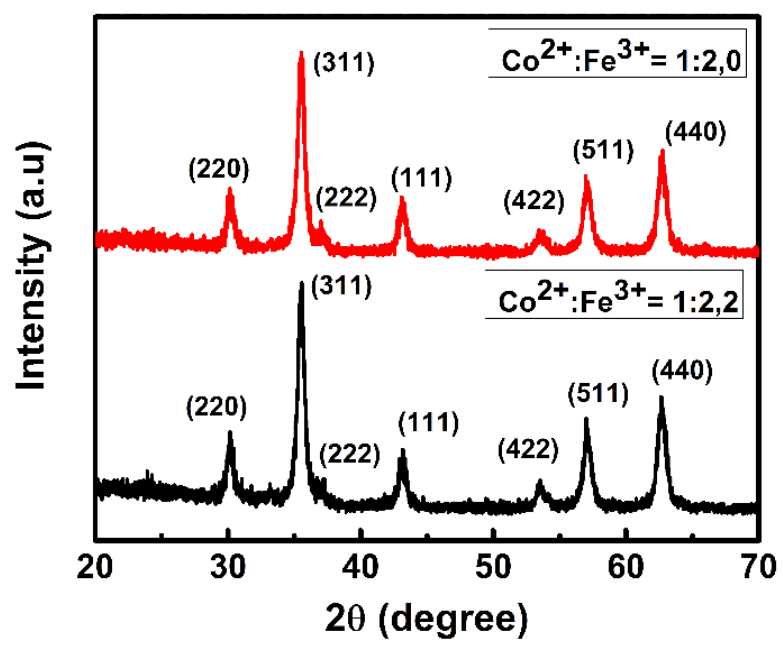

Figure 1. XRD patterns of some $\mathrm{CoFe}_{2} \mathrm{O}_{4}$ at different molar ratios. 
Different XRD patterns of cobalt ferrites corresponding to different molar ratios $\mathrm{Co}^{2+}: \mathrm{Fe}^{3+}$ are shown in Figure 1. The reflection peaks correspond to the characteristic spacing between (220), (311), (222), (111), (422), (511) and (400) planes of a cubic spinel structure, providing clear evidence of the formation of cobalt ferrite (JCPDS standard card for $\mathrm{CoFe}_{2} \mathrm{O}_{4}$ No. 01-077-0426). $\mathrm{CoFe}_{2} \mathrm{O}_{4}$ ferrite samples in fine crystalline phase, single-phase, and the crystal phase formed completely during hydrothermal processes. It is believed that in a thermos flask, $\mathrm{CoFe}_{2} \mathrm{O}_{4}$ formation reactions can take place as follows: [15]

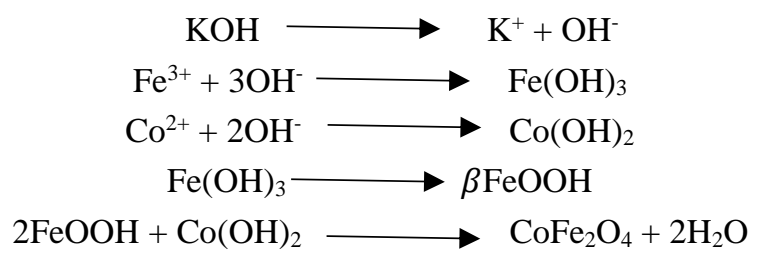

The average crystallite size of as-prepared $\mathrm{CoFe}_{2} \mathrm{O}_{4}$ ferrite particles was estimated through analysis using the classical Scherrer formular [16] $D_{\mathrm{hkl}}=\mathrm{k} \lambda / \beta \cos \theta$, where $\mathrm{D}_{\mathrm{hkl}}$ is the crystallite size derived from the (311) peak of the XRD profiles, $\mathrm{k}$ is the sphere shape factor $(0.89), \lambda$ is the wavelength of $\mathrm{X}$-ray $(1.54056 \AA), \beta$ is the full-width at half-maximum (FWHM) of the peak in radians and $\theta$ is the Braggs angle in radians. The obtained average crystallite size of as-prepared $\mathrm{CoFe}_{2} \mathrm{O}_{4}$ ferrite particles is about $15 \mathrm{~nm}$. Based on the peak central positions obtained from the high-intensity low-angle (311) and highintensity high-angle (440) peaks, the ferrite lattice parameter was estimated at $8.267 \AA$, which is in good agreement with the bulk value of $8.377 \AA$ [17].

\section{Magnetic Properties}

Various magnetic properties including saturation magnetization (Ms), coercivity (Hc), and remanent magnetization (Mr) are listed in Figure 1 and Table 2. From the values obtained, it was found that $\mathrm{CoFe}_{2} \mathrm{O}_{4}$ samples with the molar ratio of $\mathrm{Co}^{2+}: \mathrm{Fe}^{3+}=1: 2.2$ gave good magnetic results with the highest magnetization saturation $\mathrm{Ms}=58.86 \mathrm{emu} / \mathrm{g}$, which is smaller than the bulk value $(74.08 \mathrm{emu} / \mathrm{g})$ [18]. The remanence magnitude, $\mathrm{Mr}$, can be extracted from the hysteresis loop at the intersections of the loop with the vertical magnetization axis. The $\mathrm{Mr}$ value of $16.05 \mathrm{emu} / \mathrm{g}$. for nanosized ferrite particles, the surface areas are larger and thus the surface energy and surface tension are high. This results in changes in cationic preferences and leads to an increased degree of antisite defects and thus lesser magnetizations $[19,20]$. This result is used to carry out the next surveys.

\subsection{Effect of Reaction Temperature}

Temperature is one of the determinants of crystal structure and size. Since the formation of ferrite crystals has been formed during hydrothermal processes, we have conducted a hydrothermal temperature survey. We conducted a sample survey at a molar ratio of $\mathrm{Co}^{2+}: \mathrm{Fe}^{3+}=1: 2.2$, hydrothermal time for 2 hours and hydrothermal temperatures of $110^{\circ} \mathrm{C}, 130^{\circ} \mathrm{C}$, and $150^{\circ} \mathrm{C}$.

\section{Crystal Structure}

XRD patterns of $\mathrm{CoFe}_{2} \mathrm{O}_{4}$ at different reaction temperatures are shown in Figure 3. Comparing the XRD results of the sample of ferromagnetic materials made by $\mathrm{CoFe}_{2} \mathrm{O}_{4}$ to the standard XRD data of the $\mathrm{CoFe}_{2} \mathrm{O}_{4}$ sample, it was found that the samples all showed diffraction peaks and these peaks completely coincided with the standard data of the $\mathrm{CoFe}_{2} \mathrm{O}_{4}$ sample. However, in Figure 3, $\mathrm{CoFe}_{2} \mathrm{O}_{4}$ samples made at $150^{\circ} \mathrm{C}$ for diffraction peaks, are stronger and sharper than $\mathrm{CoFe}_{2} \mathrm{O}_{4}$ samples 
manufactured at $110^{\circ} \mathrm{C}$ and $130^{\circ} \mathrm{C}$. It is shown that at $150^{\circ} \mathrm{C}, \mathrm{CoFe}_{2} \mathrm{O}_{4}$ samples are the best crystallized in single-phase, and the crystalline phases formed completely during hydrothermal processes.

Table 1. Summary of the magnetic property values of $\mathrm{CoFe}_{2} \mathrm{O}_{4}$ patterns at different molar ratios

\begin{tabular}{|l|l|l|l|}
\hline Sample & Ms $(\mathrm{emu} / \mathrm{g})$ & $\mathrm{Mr}(\mathrm{emu} / \mathrm{g})$ & $\mathrm{Hc}(\mathrm{G})$ \\
\hline $\mathrm{Co}^{2+}: \mathrm{Fe}^{3+}=1: 1.6$ & 51.07 & 14.19 & 650.27 \\
\hline $\mathrm{Co}^{2+}: \mathrm{Fe}^{3+}=1: 1.8$ & 54.34 & 13.08 & 551.44 \\
\hline $\mathrm{Co}^{2+}: \mathrm{Fe}^{3+}=1: 2.0$ & 55.38 & 15.61 & 665.15 \\
\hline $\mathrm{Co}^{2+}: \mathrm{Fe}^{3+}=1: 2.2$ & 58.86 & 16.05 & 663.85 \\
\hline $\mathrm{Co}^{2+}: \mathrm{Fe}^{3+}=1: 2.4$ & 51.44 & 15.89 & 690.20 \\
\hline
\end{tabular}

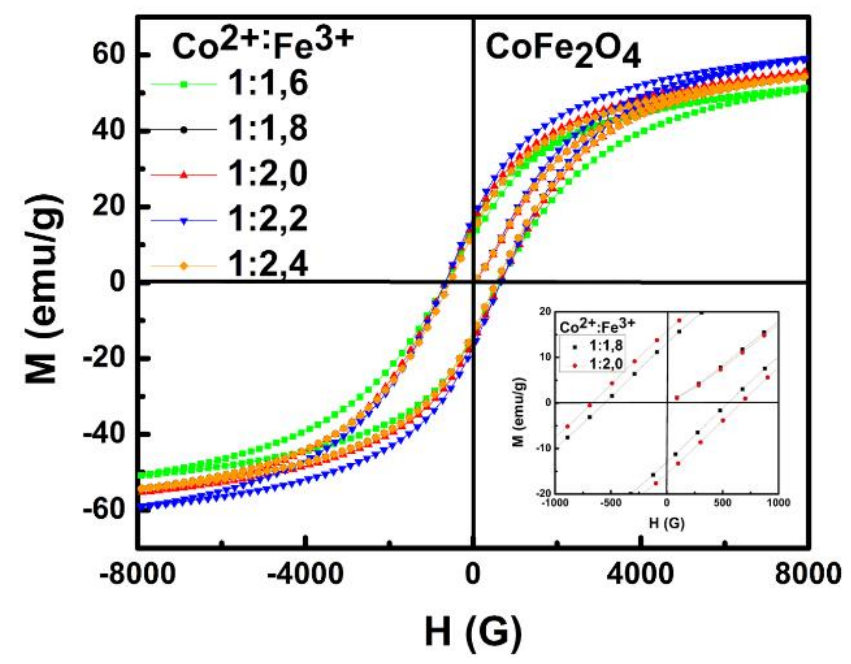

Figure 2. Hysteresis loop of $\mathrm{CoFe}_{2} \mathrm{O}_{4}$ sample at different molar ratios. The inset shows magnification around applied field of $500 \mathrm{G}$ of their loops with molar ratios of $\mathrm{Co}^{2+}: \mathrm{Fe}^{3+}$ are 1:1.8 and 1:2.0.

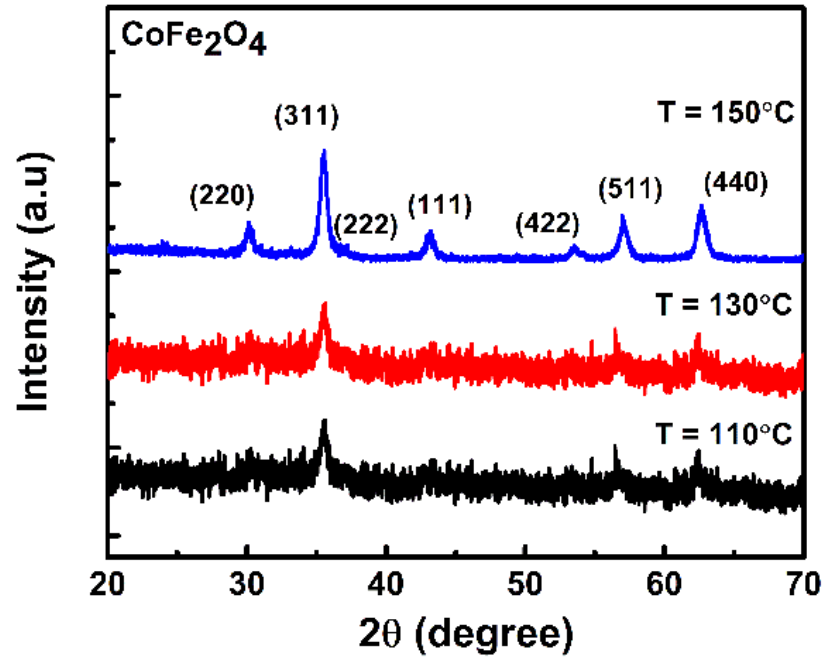

Figure 3. XRD patterns of $\mathrm{CoFe}_{2} \mathrm{O}_{4}$ sample at different reaction temperatures. 


\section{Magnetic Properties}

The hysteresis loop of $\mathrm{CoFe}_{2} \mathrm{O}_{4}$ sample at different reaction temperatures is shown in Figure 4.

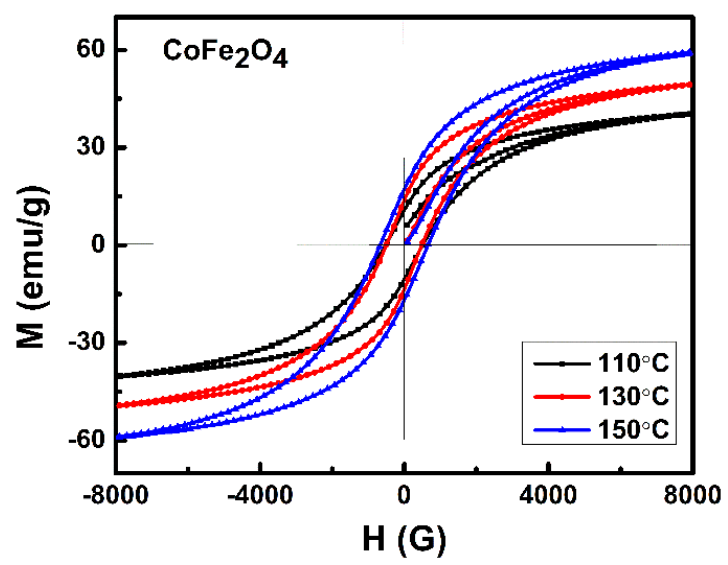

Figure 4. Hysteresis loop of $\mathrm{CoFe}_{2} \mathrm{O}_{4}$ sample at different reaction temperatures.

Figure 4 and Table 2 show that $\mathrm{CoFe}_{2} \mathrm{O}_{4}$ samples made at the temperatures of $110{ }^{\circ} \mathrm{C}, 130{ }^{\circ} \mathrm{C}$, and $150^{\circ} \mathrm{C}$ have an average coercive field $(\mathrm{Hc})$ from $490.05-663.85 \mathrm{G}$, saturation value from 40.26 to 58.86 $\mathrm{emu} / \mathrm{g}$, and residual value from $10.61-16.05 \mathrm{emu} / \mathrm{g}$. $\mathrm{CoFe}_{2} \mathrm{O}_{4}$ samples have good magnetism with the highest magnetization saturation $\mathrm{Ms}=58.86 \mathrm{emu} / \mathrm{g}$, remanence magnitude $\mathrm{Mr}=16.05 \mathrm{emu} / \mathrm{g}$ and coercivity field $\mathrm{Hc}=663.85 \mathrm{G}$ during hydrothermal process at $150^{\circ} \mathrm{C}$. It was observed that Ms value showed a positive correlation with the particle size. This was in line with Kumar et al., suggesting that increased particle size could lead to improved magnetization. This result is used to carry out subsequent surveys.

Table 2. Values of $\mathrm{CoFe}_{2} \mathrm{O}_{4}$ magnetic properties pattern at different reaction temperatures.

\begin{tabular}{|l|l|l|l|}
\hline Sample & Ms $(\mathrm{emu} / \mathrm{g})$ & $\mathrm{Mr}(\mathrm{emu} / \mathrm{g})$ & $\mathrm{H}_{\mathrm{C}}(\mathrm{G})$ \\
\hline $110^{\circ} \mathrm{C}$ & 40.26 & 10.61 & 513.62 \\
\hline $130^{\circ} \mathrm{C}$ & 49.28 & 13.63 & 490.05 \\
\hline $150^{\circ} \mathrm{C}$ & 58.86 & 16.05 & 663.85 \\
\hline
\end{tabular}

\subsection{Effect of Reaction Times}

In this context, we investigate the effect of reaction time on the structure and magnetism of $\mathrm{CoFe}_{2} \mathrm{O}_{4}$ ferrite nanoparticles with the reaction temperature of $150^{\circ} \mathrm{C}$, the molar ratio of $\mathrm{Co}^{2+}: \mathrm{Fe}^{3+}=1: 2.2$ and time varies from 1 hour to 8 hours.

\section{Crystal Structure}

The XRD structural properties of the synthesized $\mathrm{CoFe}_{2} \mathrm{O}_{4}$ pattern in Figure 5 show the characteristic peaks of the following reflection planes (220), (311), (222), (111), (511), and (440). These planes prove the presence of a spinel cubic structure. As all the $\mathrm{CoFe}_{2} \mathrm{O}_{4}$ samples, made during the raction times of 2 
hours, 4 hours, 6 hours, 7 hours and 8 hours, show good results (Figure 5), we choose the reaction time of 2 hours to perform the next experiment to shorten the experimental time.

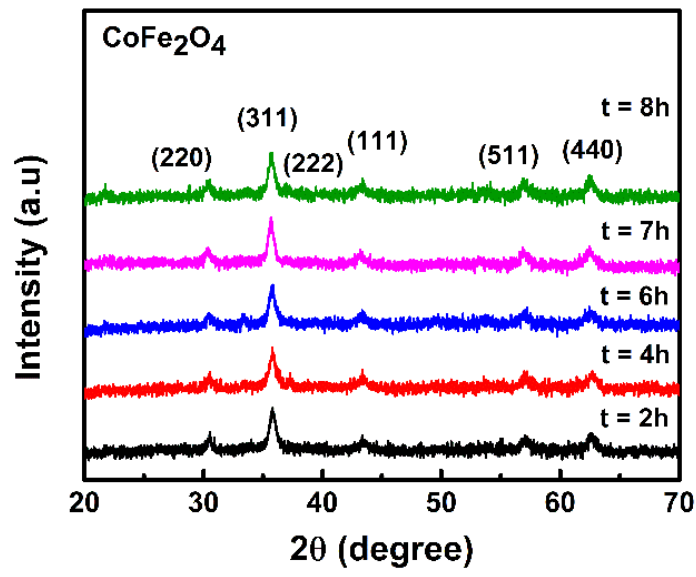

Figure 5. XRD pattern of $\mathrm{CoFe}_{2} \mathrm{O}_{4}$ at different reaction times.

\section{Magnetic Properties}

The hysteresis loop of $\mathrm{CoFe}_{2} \mathrm{O}_{4}$ sample at different reaction times is shown in Figure 6.

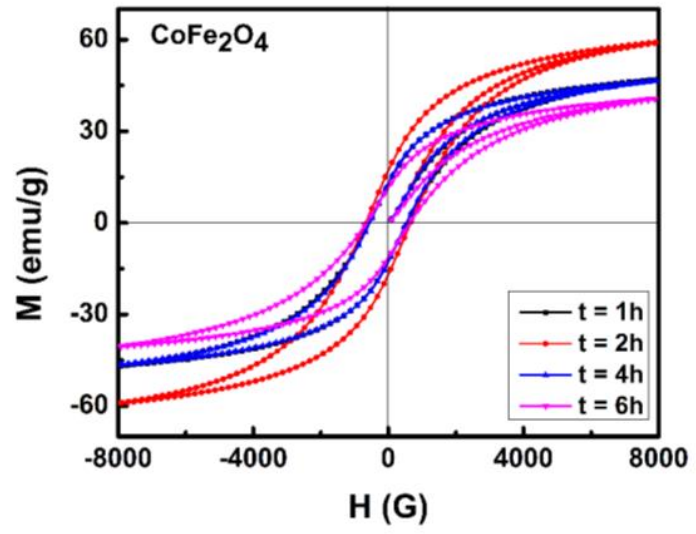

Figure 6. Hysteresis loop of $\mathrm{CoFe}_{2} \mathrm{O}_{4}$ sample at different reaction times.

Table 3. Values of the $\mathrm{CoFe}_{2} \mathrm{O}_{4}$ magnetic properties pattern at different reaction times.

\begin{tabular}{|l|l|l|l|}
\hline Sample & Ms (emu/g) & Mr $(\mathbf{e m u} / \mathbf{g})$ & Hc $(\mathbf{G})$ \\
\hline $\mathbf{1 h}$ & 46.86 & 12.62 & 557,93 \\
\hline $\mathbf{2 h}$ & 58.86 & 16.05 & 663.85 \\
\hline $\mathbf{3 h}$ & 51.86 & 15.75 & 606.14 \\
\hline $\mathbf{4 h}$ & 46.52 & 12.91 & 544.75 \\
\hline $\mathbf{5 h}$ & 42.59 & 11.73 & 628.63 \\
\hline $\mathbf{6 h}$ & 40.63 & 11.35 & 644.73 \\
\hline $\mathbf{7 h}$ & 47.02 & 14.07 & 703.67 \\
\hline $\mathbf{8 h}$ & 42.96 & 13.65 & 781.54 \\
\hline
\end{tabular}


Figure 6 and Table 3 show that the $\mathrm{CoFe}_{2} \mathrm{O}_{4}$ samples are made during timespans from 1 hour to 8 hours. The $\mathrm{CoFe}_{2} \mathrm{O}_{4}$ samples have good magnetism with the highest magnetization saturation $\mathrm{Ms}=$ $58.86 \mathrm{emu} / \mathrm{g}$, remanence magnitude $\mathrm{Mr}=16.05 \mathrm{emu} / \mathrm{g}$ and coercive field $\mathrm{Hc}=663.85 \mathrm{G}$ during the hydrothermal process at $150^{\circ} \mathrm{C}$.

\subsection{The Morphology of $\mathrm{CoFe}_{2} \mathrm{O}_{4}$ Grains}

The findings in Sections 3.1, 3.2 and 3.3 show that the $\mathrm{CoFe}_{2} \mathrm{O}_{4}$ sample made with the molar ratio of $\mathrm{Co}^{2+}: \mathrm{Fe}^{3+}=1: 2.2$ at $150^{\circ} \mathrm{C}$ during 2 hours gives the best magnetic properties; therefore, we chose this sample to examine the morphology of the $\mathrm{CoFe}_{2} \mathrm{O}_{4}$ sample (Figure 7). The results show that the morphology of the $\mathrm{CoFe}_{2} \mathrm{O}_{4}$ sample particle is spherical, nanorod-shaped with the size ranged from 13$18 \mathrm{~nm}$, which is suitable for calculating by the Scherrer equation.

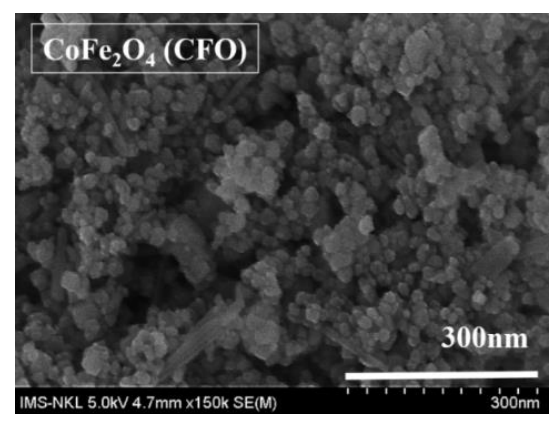

Figure 7. FE-SEM image of the $\mathrm{CoFe}_{2} \mathrm{O}_{4}$ sample.

The $\mathrm{CoFe}_{2} \mathrm{O}_{4}$ particles obtained from the experimental process show that the result of the synthesis is equivalent to or better than the results by some other recent authors. Table 4 provides comparative data on particle size and magnetic properties of as-prepared $\mathrm{CoFe}_{2} \mathrm{O}_{4}$ ferrite particles and published results by some other authors.

Table 4. Values of the $\mathrm{CoFe}_{2} \mathrm{O}_{4}$ particle magnetic properties in recent researches.

\begin{tabular}{|l|l|l|l|l|l|}
\hline No. & Material & Method & $\mathrm{d}(\mathrm{nm})$ & $\begin{array}{l}\text { Ms } \\
(\mathrm{emu} / \mathrm{g})\end{array}$ & Author \\
\hline 1 & $\mathrm{CoFe}_{2} \mathrm{O}_{4}$ & Hydrothermal & $13-18$ & 58.86 & This work \\
\hline 2 & $\mathrm{CoFe}_{2} \mathrm{O}_{4}$ & Hydrothermal & 21.32 & 53.48 & L.T. Tam [21] \\
\hline 3 & $\mathrm{CoFe}_{2} \mathrm{O}_{4}$ & Hydrothermal & 30 & $22-30$ & Chao quan Ho [22] \\
\hline 4 & $\mathrm{CoFe}_{2} \mathrm{O}_{4}$ & Hydrothermal & 50 & $\sim 50$ & Nhan, D. T. T [23] \\
\hline 5 & $\mathrm{CoFe}_{2} \mathrm{O}_{4}$ & Chemical precipitation & $10-25$ & 42.38 & Al Lehyani [24] \\
\hline 6 & $\mathrm{CoFe}_{2} \mathrm{O}_{4}$ & Chemical coprecipitation & $20-30$ & 61.77 & Zhenfa.zi [25] \\
\hline 7 & $\mathrm{CoFe}_{2} \mathrm{O}_{4}$ & Wed Chemical route & $15-48$ & 68 & Maaz K. [26] \\
\hline
\end{tabular}

\section{Conclusions}

In this study, $\mathrm{CoFe}_{2} \mathrm{O}_{4}$ spinel nanoparticles were successfully synthesized by the hydrothermal method. The effect of molar ratio, reaction temperature, and reaction time on the crystal structure, morphology, and magnetic properties of $\mathrm{CoFe}_{2} \mathrm{O}_{4}$ materials was studied. The crystallite size calculated by the Scherer formula increased from 13 to $18 \mathrm{~nm}$ under different synthesis conditions. The synthesized 
material has the best saturation magnetization $\mathrm{Ms}=58.86 \mathrm{emu} / \mathrm{g}$ when fabricated with molar ratio $\mathrm{Co}^{2+}: \mathrm{Fe}^{3+}=1: 2.2$ at $150^{\circ} \mathrm{C}$ for 2 hours.

\section{Acknowledgments}

This research is funded by the Domestic Master/PhD Scholarship Programme of Vingroup Innovation Foundation and Vietnam National Foundation for Science and Technology Development (NAFOSTED) under Grant 103.02-2019.335.

\section{References}

[1] P. T. Phong, N. X. Phuc, P. H. Nam, N. V. Chien, D. D. Dung, P. H. Linh, Size-Controlled Heating Ability of $\mathrm{CoFe}_{2} \mathrm{O}_{4}$ Nanoparticles Foráhyperthermia Applications, Physica B: Condensed Matter, Vol. 531, 2018, pp. 3034, https://doi.org/10.1016/j.physb.2017.12.010.

[2] E. R. Kumar, R. Jayaprakash, S. Kumar, Effect of Annealing Temperature on Structural and Magnetic Properties of Manganese Substituted $\mathrm{NiFe}_{2} \mathrm{O}_{4}$ Nanoparticles. Materials Science in Semiconductor Processing, Vol. 17, 2014, pp. 173-177, https://doi.org/10.1016/j.mssp.2013.09.003.

[3] U. Salazar-Kuri, J. O. Estevez, N. R. Silva-González, U. Pal, Large Magnetostriction in Chemically Fabricated $\mathrm{CoFe}_{2} \mathrm{O}_{4}$ Nanoparticles and Its Temperature Dependence, Journal of Magnetism and Magnetic Materials, Vol. 460, 2018, pp. 141-145, https://doi.org/10.1016/j.jmmm.2018.03.074.

[4] P. A. Vinosha, S. J. Das, Investigation on The Role of $\mathrm{pH}$ for The Structural, Optical and Magnetic Properties of Cobalt Ferrite Nanoparticles and Its Effect on The Photo-Fenton Activity, Materials Today: Proceedings, Vol. 5, Iss. 2, Part 3, 2018, pp. 8662-8671, https://doi.org/10.1016/j.matpr.2017.12.291.

[5] J. Tong, L. Bo, Z. Li, Z. Lei, C. Xia, Magnetic $\mathrm{CoFe}_{2} \mathrm{O}_{4}$ Nanocrystal: A Novel and Efficient Heterogeneous Catalyst for Aerobic Oxidation of Cyclohexane, Journal of Molecular Catalysis A: Chemical, Vol. 307, Iss. 1-2, 2009, pp. 58-63, https://doi.org/10.1016/j.molcata.2009.03.010.

[6] K. S. Rao, G. S. V. R. K. Choudary, K. H. Rao, Ch. Sujatha, Structural and Magnetic Properties of Ultrafine $\mathrm{CoFe}_{2} \mathrm{O}_{4} \quad$ Nanoparticles, Procedia Materials Science, Vol. 10, 2015, pp. 19-27, https://doi.org/10.1016/j.mspro.2015.06.019.

[7] P. C. R. Varma, R. S. Manna, D. Banerjee, M. R. Varma, K. G. Suresh, A. K. Nigam, Magnetic Properties of $\mathrm{CoFe}_{2} \mathrm{O}_{4}$ Synthesized by Solid State, Citrate Precursor and Polymerized Complex Methods: A Comparative Study, Journal of Alloys and Compounds, Vol. 453, Issues 1-2, 2008, pp. 298-303, https://doi.org/10.1016/j.jallcom.2006.11.058.

[8] N. Dong, F. He, J. Xin, Q. Wang, Z. Lei, B. Su, Preparation of $\mathrm{CoFe}_{2} \mathrm{O}_{4}$ Magnetic Fiber Nanomaterial Via A Template-Assisted Solvothermal Method, Materials Letters, Vol. 141, 2015, pp. 238-241, https://doi.org/10.1016/j.matlet.2014.11.054.

[9] A. Maleki, N. Hosseini, A. Taherizadeh, Synthesis and Characterization of Cobalt Ferrite Nanoparticles Prepared by The Glycine-Nitrate Process, Ceramics International, Vol. 44, Iss. 7, 2018, pp. 8576-8581, https://doi.org/10.1016/j.ceramint.2018.02.063.

[10] M. A. Gabal, A. A. Al-Juaid, S. El-Rashed, M.A. Hussein, Synthesis and Characterization of Nano-Sized $\mathrm{CoFe}_{2} \mathrm{O}_{4}$ Via facile Methods: A Comparative Study, Materials Research Bulletin, Vol. 89, 2017, pp. 68-78, https://doi.org/10.1016/j.materresbull.2016.12.048.

[11] B. Pourgolmohammad, S. M. Masoudpanah, M.R. Aboutalebi, Synthesis of $\mathrm{CoFe}_{2} \mathrm{O}_{4}$ Powders With High Surface Area by Solution Combustion Method: Effect of Fuel Content and Cobalt Precursor, Ceramics International, Vol. 43, Iss. 4, 2017, pp. 3797-3803, https://doi.org/10.1016/j.ceramint.2016.12.027.

[12] D. R. Babu, K. Venkatesan, Synthesis of Nanophasic $\mathrm{CoFe}_{2} \mathrm{O}_{4}$ Powder by Self-Igniting Solution Combustion Method Using Mix Up Fuels, Journal of Crystal Growth, Vol. 468, 2017, pp. 179-184, https://doi.org/10.1016/j.jcrysgro.2016.11.054. 
[13] S. Kumar, S. Munjal, N. Khare, Metal-Semiconductor Transition and Seebeck Inversion in $\mathrm{CoFe}_{2} \mathrm{O}_{4}$ Nanoparticles, Journal of Physics and Chemistry of Solids, Vol. 105, 2017, pp. 86-89, https://doi.org/10.1016/j.jpcs.2017.02.003.

[14] N. T. T. Loan, N. T. H. Lan, N. T. T. Hang, N. Q. Hai, D. T. T. Anh, V. T. Hau, L. V. Tan, T. V. Tran, $\mathrm{CoFe}_{2} \mathrm{O}_{4}$ Nanomaterials: Effect of Annealing Temperature on Characterization, Magnetic, Photocatalytic, and Photo-Fenton Properties, MDPI Journals, Vol. 7, Iss. 12, 2019, pp. 885, https://doi.org/10.3390/pr7120885.

[15] H. Li, H. Z. Wu, G. X. Xiao, Effects of Synthetic Conditions on Particle Size and Magnetic Properties of $\mathrm{NiFe}_{2} \mathrm{O}_{4}$, Powder Technology, Vol. 198. Iss. 1, 2010, pp. 157-166, https://doi.org/10.1016/j.powtec.2009.11.005

[16] M. I. Mendelson, Average Grain Size in Polycrystalline Ceramics, Journal of The American Ceramic Society, Vol. 52, Iss. 8, 1969, pp. 443-446, https://doi.org/10.1111/j.1151-2916.1969.tb11975.x.

[17] T. Meron, Y. Rosenberg, Y. Lereah, G. Markovich, Synthesis and Assembly of High-Quality Cobalt Ferrite Nanocrystals Prepared by A Modified Sol-Gel Technique, Journal of Magnetism and Magnetic Materials, Vol. 292, 2005, pp. 11-16, https://doi.org/10.1016/j.jmmm.2004.10.084.

[18] M. P. Gonzalez-Sandoval, A. M. Beesley, M. Miki-Yoshida, L. Fuentes-Cobas, J. A. Matutes-Aquino, Comparative Study of The Microstructural and Magnetic Properties of Spinel Ferrites Obtained by Co-Precipitation, Journal of Alloys and Compounds, Vol. 369, No. 1-2, 2004, pp. 190-194, https://doi.org/10.1016/j.jallcom.2003.09.101.

[19] S. Calvin, E. E. Carpenter, B. Ravel, V. G. Harris, S. A. Morrison, Multiedge Refinement of Extended X-rayAbsorption Fine Structure of Manganese Zinc Ferrite Nanoparticles, Physical Review B, Vol. 66, Iss. 22, 2002, pp. 224405, https://doi.org/10.1103/PhysRevB.66.224405.

[20] D. J. Fatemi, V. G. Harris, V. M. Browning, J. P. Kirkland, Processing and Cation Redistribution of MnZn Ferrites Via High-Energy Ball Milling, Journal of Applied Physics, Vol. 83, Iss. 11, 1998, pp. 6867-6869, https://doi.org/10.1063/1.367766.

[21] L. T. Tam, N. H. Du, L. T. H. Nhung, D. T. N. Hang, P. T. Dung, N. M. Duc, T. T. P. Thu, Characterization of Cobalt Ferrite $\mathrm{CoFe}_{2} \mathrm{O}_{4}$ Nanoparticles Synthesized by Co-Precipitation and Hydrothermal Methods, Journal of science of Vinh university, Vol. 46, No. 2A, pp. 58-65.

[22] C. Hu, Z. Gao, X. Yang, X, One-pot Low Temperature Synthesis of $\mathrm{MFe}_{2} \mathrm{O}_{4}(\mathrm{M}=\mathrm{Co}, \mathrm{Ni}, \mathrm{Zn})$ Superparamagnetic Nanocrystals, Journal of Magnetism and Magnetic Materials, Vol. 320, Iss. 8, 2008, pp. L70-L73, https://doi.org/10.1016/j.jmmm.2007.12.006.

[23] D. T. T. Nhan, L. L. Son, L. Q. Thang, Study, Synthesis, Characterization, and Application of Chitosan-Ferrite Magnetic Films With Optical Structure (in Vietnamese), Vietnam Journal of Chemistry, Vol. 56, Iss. 3, 2018, pp. 384-388, https://doi.org/10.15625/vjc.2018-0038.

[24] S. H. A. Al Lehyani, R.A. Hassan, A. A. Alharbi, T. Alomayri, H. Alamri, Magnetic Hyperthermia Using Cobalt Ferrite Nanoparticles: The Influence of Particle Size, International Journal of Advancements in Technology, Vol.8, Iss. 4, 2017, pp. 1000196-1000201, https://doi.org/10.4172/0976-4860.1000196 .

[25] Z. Zi, Y. Sun, X. Zhu, Z. Yang, J. Dai, W. Song, Synthesis and Magnetic Properties of $\mathrm{CoFe}_{2} \mathrm{O}_{4} \mathrm{Ferrite}$ Nanoparticles, Journal of Magnetism and Magnetic Materials, Vol. 321, Iss. 9, 2009, pp. 1251-1255, https://doi.org/10.1016/j.jmmm.2008.11.004.

[26] K. Maaz, A. Mumtaz, S. K. Hasanain, A. Ceylan, Synthesis and Magnetic Properties of Cobalt Ferrite $\left(\mathrm{CoFe}_{2} \mathrm{O}_{4}\right)$ Nanoparticles Prepared by Wet Chemical Route, Journal of Magnetism and Magnetic Materials, Vol. 308, Iss. 2 , 2007, pp. 289-295, https://doi.org/10.1016/j.jmmm.2006.06.003. 